\title{
Assessment of Constraints and Opportunities of Tea Out-Growers in South West Ethiopia
}

\author{
Beza Erko Erge ${ }^{1}$ Melaku Addisu Bifa ${ }^{2} \quad$ Megdelawit Temesgen $^{1} \quad$ Efrem Asfaw $^{1} \quad$ Rehima Musema $^{3}$ \\ 1.Agricultural Economist in Jimma Agricultural Research Center. Ethiopian Institute of Agricultural Research \\ (EIAR), Jimma, Ethiopia \\ 2.Coffee and Tea breeder in Jimma Agricultural Research Center. Ethiopian Institute of Agricultural Research \\ (EIAR), Jimma, Ethiopia \\ 3.Agricultural Economist in. Ethiopian Institute of Agricultural Research (EIAR), Addis Ababa, Ethiopia
}

\begin{abstract}
This research attempted to generate useful information on tea out growers' constraints and opportunities in tea production and marketing, which helps governmental institutions to assess their activities and redesign their operations. The research was done by interviewing tea out growers surrounding the two major tea plantations Wush Wush and Gumero in south west Ethiopia. Data was collected from 120 randomly selected households. Data was analyzed using descriptive statistics and Relative Severity Index to analyze constraints. The obtained result showed that, out-growers on average allocated 1.37 ha land to produce tea. They plucked on average $295 \mathrm{~kg} / \mathrm{ha}$ export standard or $731 \mathrm{~kg} / \mathrm{ha}$ local standard green tea leaves in one harvest in main season. Relative Severity index analysis revealed that out growers' major constraints of tea production were high price and timely availability of inputs, shortage of inputs, high cost of production, need intensive plot management, lack of capital, no government intervention and extension service and lack of training. However, they have good opportunities in obtaining frequent income almost throughout the year, high cash income, low risk of animal damage and theft.
\end{abstract}

Keywords: Tea out growers, Gumero, Wush Wush, Relative Severity Index, constraints.

DOI: $10.7176 / J E S D / 12-19-04$

Publication date:October $31^{\text {st }} 2021$

\section{Introduction}

Ethiopia's overall economic and social development is highly dependent on the growth and development of the agriculture sector which contributes almost half of the GDP, employs about $85 \%$ of the labor force, accounts for about $75 \%$ of the foreign exchange earnings, and provides livelihood for over $80 \%$ of the population living mainly in rural areas (CSA, 2015). After decades of stagnation, the sector has shown remarkable growth at an average rate of $11 \%$ per annum since 2005 (MoFED, 2010). Since Ethiopian Government made agriculture its primary priority in 1991, the country has developed and implemented its Agricultural Development Led-Industrialization (ADLI) strategy. The key concept underlying ADLI is an export-led development strategy aimed at promoting economic growth in Ethiopia while coordinating agricultural and industrial development. As export diversification and import substitution program in the country, tea is one of the strategic crops with significant importance in the national economy, which has been given due emphasis by the government to intensify its production and productivity by subsistent farmers and large scale farming.

Tea (Camellia sinensis L.) is one of the most important cash crops of many countries, including Ethiopia. Currently, tea is the most widely consumed stimulant beverage worldwide followed by coffee, and accounts for about $46 \%$ of the world's beverage market. It is served as morning drink for nearly two-third of the world population. For use as stimulant, the young shoots (leaves, leaf buds, and internodes) of the tea plant are harvested and processed using various methods. It is consumed in several forms depending on the type of processing technique involved. Of the different tea types; white, yellow, green, oolong and black tea are the major ones prepared and marketed in the world (Sharma et.al, 2007).

In Ethiopia, tea is grown in the highland areas that can offer ideal climatic conditions and soil types for production and processing of good quality tea for export and domestic consumption. Currently, tea is largely produced by three estates namely Ethio-Agri-Ceft PLC (WushWush and Gumero Tea Development) and East Africa PLC (Chewaka Tea Development) in south west Ethiopia. To date, total of 2660 ha of land has been devoted to estate tea plantations. Moreover, a total of 581 out-growers are growing tea on 439 ha of land in the vicinities of the three large scale tea plantations under the region (Tea research strategy, 2017). The small scale farmers have been organized in associations to produce and supply green leaves to the companies.

In the last GTP-I period, a total of 4570.78 ton of tea has been supplied for export market and 34,126.1 ton supplied to local markets. The tea development has provided employment and income opportunities to the 581 out-growers, 7139 temporary and 1157 permanent workers at the tea estates in southwestern Ethiopia, although the current out-grower schemes call for legal modalities to support maximized benefits from the tea industry as compared to other producing countries.

Despite the favourable environmental conditions for the production of quality tea in Ethiopia, its production 
and productivity has not been improved. Direct adoption of all tea production packages from abroad is mainly due to the weak and infant stage of tea research in the country. In the present day where the expansion of small scale farmers/out-growers is considerably undertaking, there should be an urgent measure to develop effective extension service and build-up of a strong tea research program benefiting the rapidly growing up tea out growers in particulars and the sector at large. Hence, assessing constraints and opportunities of tea production and marketing contributes to identify gaps and basis for further research towards the adaptation, generation and adoption of technologies suiting to Ethiopian conditions. Therefore, this study was undertaken to address the following objectives.

\section{Objectives of the study}

- To assess production and marketing constraints of tea that limit smallholder farmers in improving tea production, productivity and supply;

- To identify opportunities that contribute to the benefit of small scale out growers in the production and marketing of tea, and

- To suggest feasible and practicable research intervention options that are believed to address tea outgrowers major constraints.

\section{Methodology}

Study areas

The study was conducted in Alle and Gimbo districts in Southwest parts of Ethiopia. They are the most important tea growing region in the country. In the areas, there were few smallholder tea growers supplying green tea leaves to Wush Wush and Gumero TeaProcessing factories. The Wush Wush Tea Plantation is located at latitude 7.3098 North and longitude 36.0999 East. And Gumero Tea Plantation is located at latitude 8.1669 North and longitude 35.4924 East.

\section{Data collection method}

Data was collected from primary and secondary sources. The Primary (field) data was collected by interviewing smallholder tea growers (out-growers) using questionnaire developed for quantitative information and through Focal Group Discussion (FGD) for qualitative information. The FGD is useful in the condition when data cannot be captured by questionnaire. Secondary data was collected from tea plantation. Academic literature and comparative studies from other countries were also reviewed.

\section{Data collection Techniques and Approaches}

Blends of tools and techniques were adopted to collect the required information and dataset that address the objectives of the study. Three standard data collection techniques and approaches were employed. These were desk review, qualitative assessments and quantitative survey techniques. The first stage focuses on generating secondary information while the second and third stages target in collecting primary information from target respondents. The second stage intends to generate information using a checklist while the third stage deals with generating quantitative information using a structured questionnaire.

\section{Sampling frame and sample selection}

The sampling frame of the study for quantitative survey is the population of smallholder tea growers in the location under consideration. The sampling frame could be stratified into homogenous components where sample respondents drawn from. Accordingly, the sampling frame was stratified into out growers surrounding Wush Wush and Gumero Tea plantations that are located in Gimbo and Alle districts in south West Ethiopia, respectively.

Even though the size of the sample can be determined using the rule of thumb approach, such as selecting either $5 \%$ or $10 \%$ of the population, there is no hard and fast rule to determine the size of the sample proposing as $5 \%$ or $10 \%$. This is because; the mere size alone does not ensure representativeness. Sample size for this study should neither be too small nor too large, but it should be optimum. The optimum sample size is the one that fulfils the requirements of efficiency, representativeness, reliability and flexibility.

In general, consideration of the above factors made reasonable decision in determining the fair size of the sample in the study. In addition to this, the study employed the following sample size determination formula (Yamane, 1967):

$$
n=\frac{N}{1+N(e)^{2}}
$$

Where " $\mathrm{n}$ " is the sample size, "N" is the population size, and "e" is the level of precision. In this study, the level of precision desired was $92.5 \%$ and therefore, "e" was set at 0.075 . 
The study was conducted by purposively selecting two districts and six kebeles ( 3 per district). Smallholder tea growers were selected randomly from each kebele. Accordingly, a total of 120 tea growing household heads were selected for the study. In addition, Wush Wush and Gumero Tea Plantations were interviewed.

\section{Data analysis}

The data collected based on the developed questionnaires was coded and directly entered into a computer on SPSS spreadsheet. The data was analyzed using descriptive statistics to compute frequency, percentage, mean, standard deviation, minimum and maximum values. Moreover, simple tests such as ttest and chi square were computed to compare categorical variables between groups and to compare means between the two groups.

Relative Severity Index (RSI) (Chandima W., et al, 2017) was used to determine the relative importance of constraints out growers faced and opportunities they have. Two point scale: issue was important or not important as the perception of smallholder farmers. Important scale has a weight of 5 and not important has weight of 1 . This scale and weight was transformed to Relative Severity index for each constraint and opportunity using the following equation.

\section{Where}

$$
R S I=\frac{\sum_{i=1}^{N} \mathrm{Wi}}{\mathrm{H} * \mathrm{~N}}
$$

RSI- Relative Severity Index

$\mathrm{Wi}$ - is the weight given to each constraints or opportunities which in this case scaled as 5 and 1. It is computed as frequency of each constraint/opportunity multiplied by scale assigned.

$\mathrm{H}$ - is the highest scale/weight in this case 5.

$\mathrm{N}$ - is the total number of respondents (frequency of respondents).

\section{Results and Discussion}

The two main Tea Development Farms in Ethiopia, Wush Wush and Gumero, have made contract farming with out-growers in their surrounding kebeles. The Wush Wush tea farm started the contract farming with tea out growers in 2005 in Michity kebele with five out growers on 25 ha of land. Currently, the number of outgrowers has expanded to six kebeles namely Michity, Yebeto, Bita Chega, Woka Araba, Tega and Chereba. On the other hand, Gumero tea farm started contract farming with out-growers in 2011 in Jato Weraka kebele with seven out growers. Currently, the number of outgrowers has expanded to seven kebeles, namely Gibe, Jeto Weraka, Mora, Onga, Gumero Abo, Agalo and Hobe.

The present study was thus conducted considering the tea out-groweres found in kebeles around the two main Tea Developments farms in southwest Ethiopia. Data was collected on 120 tea out growers from six kebeles surrounding the two major big Tea farms. The distribution of ssamplings considered for the study purpose is asindicated in table-1.

Table-1. Population and sample size of out- growers in the study areas

\begin{tabular}{|c|c|c|c|c|c|c|}
\hline \multirow[t]{2}{*}{ Region } & \multirow[t]{2}{*}{ Zone } & \multirow[t]{2}{*}{ District } & \multirow[t]{2}{*}{$\begin{array}{l}\text { Total out -growers in } \\
\text { the District (No) }\end{array}$} & \multirow[t]{2}{*}{$\begin{array}{l}\text { Area covered by } \\
\text { out-growers (ha) }\end{array}$} & \multirow[t]{2}{*}{$\begin{array}{l}\text { Sample } \\
\text { Kebele }\end{array}$} & $\begin{array}{c}\text { Sample } \\
\text { size }\end{array}$ \\
\hline & & & & & & $\mathrm{n}$ \\
\hline \multirow[t]{3}{*}{ Oromia } & \multirow[t]{3}{*}{ Iluababor } & \multirow[t]{3}{*}{ Alle } & \multirow[t]{3}{*}{118} & \multirow[t]{3}{*}{143} & Agalo & 19 \\
\hline & & & & & Gumero Abo & 20 \\
\hline & & & & & Jto Wereka & 19 \\
\hline \multirow[t]{3}{*}{ SNNP } & \multirow[t]{3}{*}{ Kefa } & \multirow[t]{3}{*}{ Gimbo } & \multirow[t]{3}{*}{287} & \multirow[t]{3}{*}{395} & Bita Chega & 19 \\
\hline & & & & & Michity & 23 \\
\hline & & & & & Yebeto & 20 \\
\hline \multicolumn{3}{|c|}{ Total } & 405 & 538 & Total & 120 \\
\hline
\end{tabular}

In the study areas, demographic characteristics of out-growers result showed that $94 \%$ of household heads were male. Most of the out-growers' primary occupation were farming and about $6 \%$ of them were either government employers or self employed in other business. The result showed that $58 \%$ of household heads of out growers were educated having an education level of grade 7 to grade 12 . This could be assumed as one of the factors among others which might have leaded the out-growers to early adoption of tea production practices/technologies in the region (Table 2). 
Table-2: Demographic characteristics of out-growers in study areas

\begin{tabular}{|c|c|c|c|c|c|c|c|c|c|}
\hline \multirow[t]{2}{*}{ Variables } & \multirow[t]{2}{*}{ Variable category } & \multicolumn{2}{|c|}{$\begin{array}{l}\text { Alle district } \\
\text { (Gumero) }\end{array}$} & \multicolumn{2}{|c|}{$\begin{array}{c}\text { Gimbo } \\
\text { district } \\
\text { (Wush } \\
\text { Wush) }\end{array}$} & \multicolumn{2}{|c|}{ Total } & \multirow[t]{2}{*}{ Chi $^{2}$} & \multirow[t]{2}{*}{ Pr. } \\
\hline & & $\mathrm{n}$ & $\%$ & $\mathrm{n}$ & $\%$ & $\mathrm{n}$ & $\%$ & & \\
\hline \multirow{3}{*}{$\begin{array}{l}\text { Primary occupation } \\
\text { of out growers }\end{array}$} & Farming & 53 & 91 & 59 & 95 & 112 & 94 & \multirow[b]{3}{*}{2.858} & \multirow[b]{3}{*}{0.414} \\
\hline & Gov. employment & 4 & 7 & 2 & 3 & 6 & 5 & & \\
\hline & Others & 1 & 2 & 1 & 2 & 1 & 1 & & \\
\hline \multirow{4}{*}{$\begin{array}{l}\text { Education level of } \\
\text { household heads }\end{array}$} & Illiterate & 4 & 3 & 10 & 8 & 14 & 12 & \multirow{4}{*}{5.106} & \multirow{4}{*}{0.164} \\
\hline & $\begin{array}{ll}\text { Primary } & \text { school } \\
\text { (Grade 1-4) } & \end{array}$ & 17 & 14 & 12 & 10 & 29 & 24 & & \\
\hline & $\begin{array}{ll}\begin{array}{l}\text { Secondary } \\
(\text { Grade } 7-12)\end{array} & \text { school } \\
\end{array}$ & 32 & 27 & 38 & 32 & 70 & 58 & & \\
\hline & $\begin{array}{l}\text { Higher education } \\
\text { (Above grade } 12 \text { ) }\end{array}$ & 5 & 4 & 2 & 2 & 7 & 6 & & \\
\hline
\end{tabular}

Socio-economic characteristics result showed that of $93 \%$ of tea out growers' primary occupation were farming while $7 \%$ were employers and engage in other business. They on average have age of 42 years old and have a family size of six persons. Very few out growers started growing tea 15 years ago. Currently out growers in the study areas on average have five years experience and owned on average 4.3 ha of land of which allocated 1.4 ha of land to produce tea. There was statistically significant difference between the two districts in age of household age, family size and land covered by perennial crop at 5\% significance levels. Details of socio-economic variables described in table 3 below.

Table-3. Socio-economic characteristics of out-growers in study areas.

\begin{tabular}{|l|c|c|c|c|c|c|c|c|}
\hline & \multicolumn{2}{|c|}{$\begin{array}{c}\text { Alle district } \\
\text { Variables }\end{array}$} & \multicolumn{2}{|c|}{$\begin{array}{c}\text { Gimbo district } \\
\text { (Wush } \\
\text { Wush) }\end{array}$} & \multicolumn{2}{c|}{ Total } & \multirow{2}{*}{ Sign. } \\
\cline { 2 - 8 } & mean & St.dv & mean & St.dv & mean & St.dv & & \\
\hline Age of HH head & 39.48 & 13.199 & 43.97 & 14.687 & 41.80 & 14.110 & - & $0.041^{* *}$ \\
\hline Family size & 5.64 & 2.79 & 6.7 & 2.891 & 6.19 & 2.888 & - & $0.022^{* *}$ \\
\hline Total land owned (ha) & 4.75 & 4.308 & 3.99 & 2.324 & 4.35 & 3.437 & 1.090 & 0.139 \\
\hline $\begin{array}{l}\text { Tea land currently owned } \\
\text { (ha) }\end{array}$ & 1.38 & 1.85 & 1.36 & 1.239 & 1.37 & 1.557 & 0.043 & 0.433 \\
\hline $\begin{array}{l}\text { Experience in tea } \\
\text { production (years) }\end{array}$ & 5.22 & 2.302 & 4.74 & 2.78 & 4.97 & 2.563 & 1.024 & 0.154 \\
\hline
\end{tabular}

South west of Ethiopia is a forest area. However, $96 \%$ of out-growers used open farm land (i.e. neither forest nor semi-forest land) to grow tea. They shift annual crop land such as maize, sorghum and teff land to tea plots. More out growers (85\%) replaced maize and teff plots by tea (Table-4).

Table 4. Land used to grow tea in the study areas

\begin{tabular}{|c|c|c|c|c|c|c|c|c|c|}
\hline \multirow[t]{2}{*}{ Variables } & \multirow[t]{2}{*}{$\begin{array}{l}\text { Variable } \\
\text { category }\end{array}$} & \multicolumn{2}{|c|}{$\begin{array}{l}\text { Alle district } \\
\text { (Gumero) }\end{array}$} & \multicolumn{2}{|c|}{$\begin{array}{l}\text { Gimbo district } \\
\text { (Wush } \\
\text { Wush) }\end{array}$} & \multicolumn{2}{|c|}{ Total } & \multirow[t]{2}{*}{$\mathrm{Chi}^{2}$} & \multirow[t]{2}{*}{ Pr. } \\
\hline & & $\mathrm{n}$ & $\%$ & $\mathrm{n}$ & $\%$ & $\mathrm{n}$ & $\%$ & & \\
\hline \multirow{2}{*}{$\begin{array}{l}\text { Tea plot } \\
\text { size trend }\end{array}$} & Expanded & 32 & 55 & 43 & 70 & 75 & 63 & \multirow[b]{2}{*}{2.994} & \multirow[b]{2}{*}{$0.094 *$} \\
\hline & $\begin{array}{l}\text { More or less } \\
\text { the same }\end{array}$ & 26 & 45 & 18 & 30 & 44 & 37 & & \\
\hline \multirow{3}{*}{$\begin{array}{l}\text { Land used } \\
\text { for tea } \\
\text { growing }\end{array}$} & Open farm land & 56 & 97 & 58 & 94 & 114 & 96 & \multirow{3}{*}{3.904} & \multirow{3}{*}{0.272} \\
\hline & Semi forest & 0 & 0 & 3 & 5 & 3 & 3 & & \\
\hline & Forest & 1 & 2 & 0 & 0 & 1 & 1 & & \\
\hline
\end{tabular}

Almost all out growers replaced their annual crop land such as maize land to grow tea. Only $1 \%$ of them replaced coffee land to grow tea. The main reasons for replacing annual crop farm land to tea plot were as the areas are forest, to grow annual crop hardly possible. However, tea is not damaged by wild animals and stolen by theft Moreover, as tea is an perennial crop, it has high future prospect; it generates high and frequent income than annual 
crops (Figure 1).

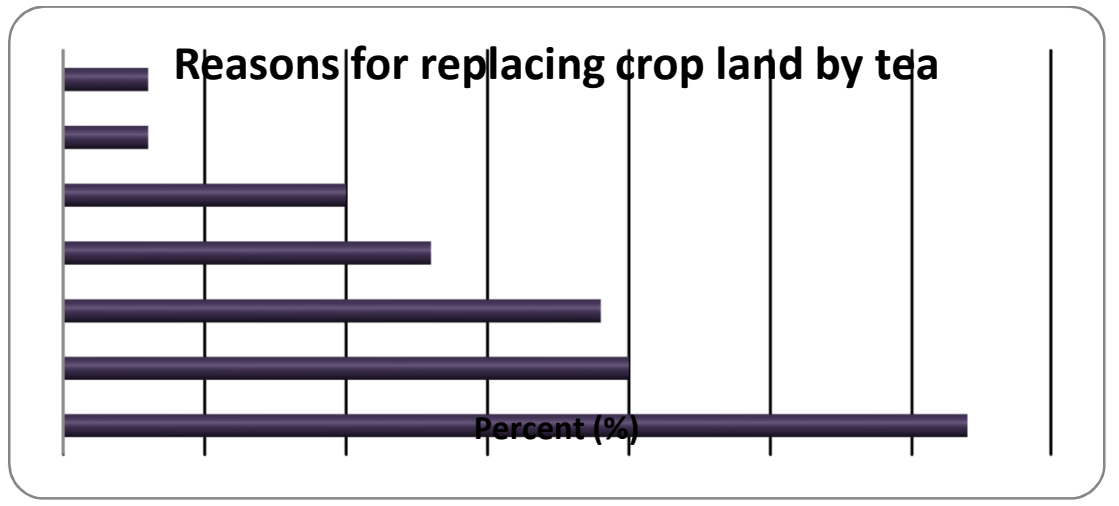

Figure 1. Reasons for replacing annual crop land to tea

Out-growers in the study areas started growing tea on allocated average land area of 0.59 ha and currently this figure increased to 1.37 ha of land. About $63 \%$ of them expanded their tea plot size. The most important reasons for expanding tea land area were that the tea farm generated high income and provided more economic benefit than other crops production (figure.2).

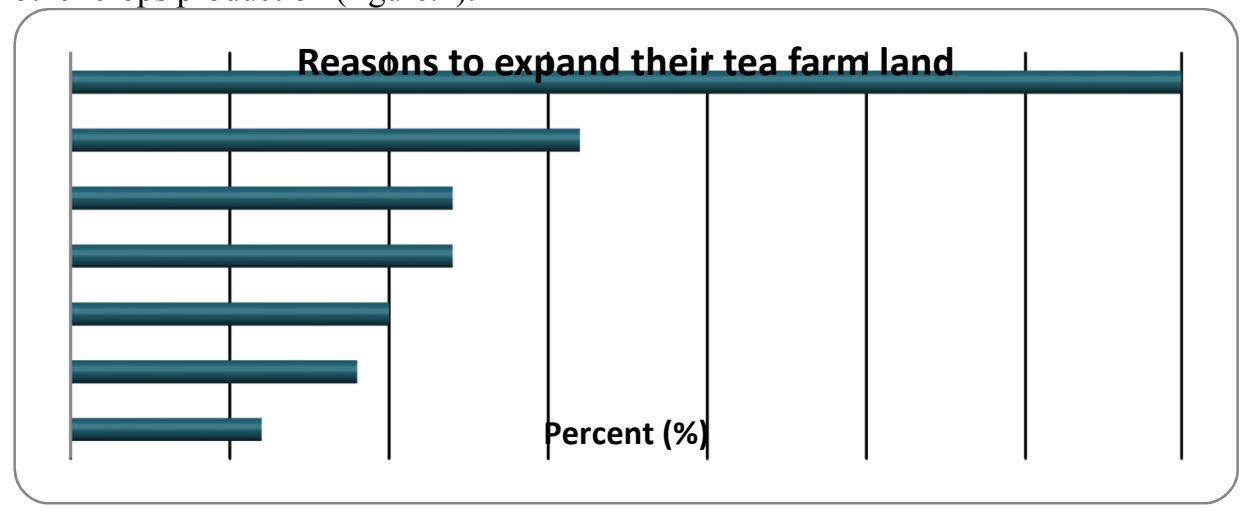

Figure 2. Reasons of out growers to expand tea farm land

Out growers used improved tea production technologies such as varieties called clones, inorganic fertilizer, weeding, harvesting, etc. The technologies such as clones and improved agronomic practices were introduced from abroad and supplied to out growers by the two tea estates such as Wushwush and Gumero tea plantations. The type of clones grown by out-growers were 11/56, SR, 11/4, BB35 and 6/8. Majority of them planted two types of clones. Around Wush Wush Tea plantation prefer tea clones; 11/56 and SR while out growers surrounding Gumero Tea plantation prefer $11 / 4$ and BB/35 clones. The main reasons for these clones preference were high yield, fast regeneration recovery from pruning and drought tolerance (Figure 3 and 4 .

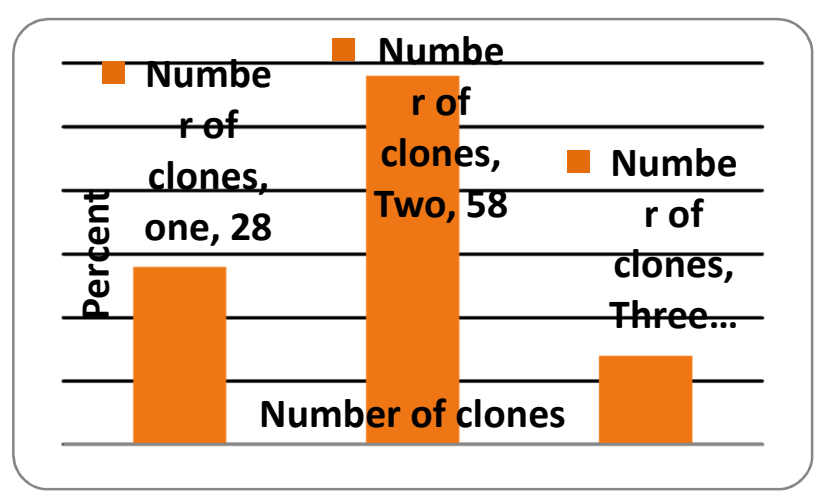

Figure 3. Number of tea clones planted by out growers

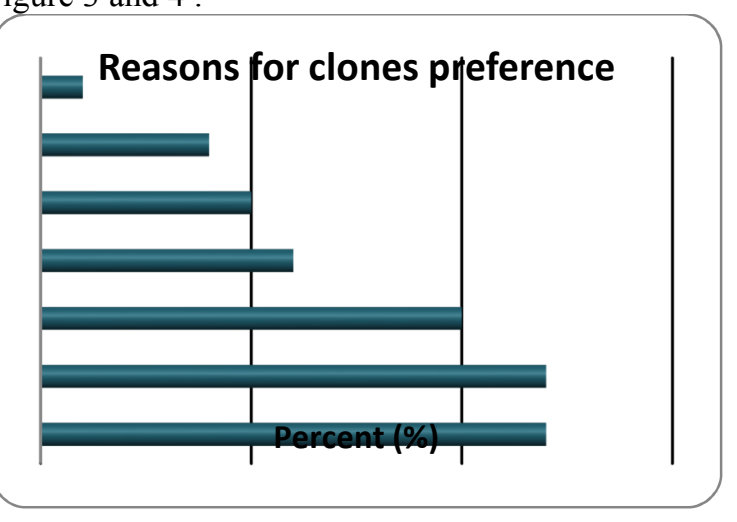

Figure 4. Reason for tea clone preference

Tea production requires intensive inputs such as fertilizer and labor for land preparation, weeding, stumping/pruning and plucking/harvesting. In order to boost tea production, out-growers used inorganic fertilizer (NPS/NPK and UREA). Only $3 \%$ of them used organic fertilizer (compost or manure). They were supplied with farm inputs such as seedlings, fertilizer, and pesticide and farm implements. Except tea seedlings, other inputs were supplied with payments. The term of payment for fertilizer was a type of loan to be deducted from some 
proportion of their income received from green leaf supply. The loan deducted and finished within six months. The price of NPK fertilizer was $1792 \mathrm{ETB} / \mathrm{qt}$ where they were found to deliver $176 \mathrm{~kg}$ of export standard green leaf to pay back $50 \mathrm{~kg}$ of NPK fertilizer. The recommended rate of fertilizer application was $300 \mathrm{~kg} /$ ha. However, out growers applied on average $234 \mathrm{~kg}$ of fertilizer (NPS/NPK + UREA) per year and $88 \%$ of them applied this amount two times in split applications. Weed management is one of the labor demanding activities in tea production. Most Out-growers (92\%) practiced both hand weeding and chemical (pesticide) to control weed. About $65 \%$ of them applied chemicals twice a year. The recommended rate of this chemical was 2 liter/ha and supplied by the estates with a price of $86 \mathrm{ETB} / \mathrm{ha}$.

Tea is amongst the most labor intensive perishable crop especially during the plucking period as leaves harvested every 15 to 20 days. It provides job opportunity for rural community. Therefore, tea farm operation cannot be managed only by a family labor like some other crops. Almost all field operations such as land preparation, planting, weeding and pruning/stumping require hired labor in addition to family labor. The result showed that out growers used high hired labor relative to other crops in all farm operation. In the study areas, $30 \%$ - 38\% of out growers used hired labor only for land preparation, planting and weeding. This proportion is very high for plucking in which $75 \%$ of out growers used hired labor only for harvesting. There is statistically high significant difference between the two areas in using the sources of labor for land preparation and planting. For example, out growers in Alle district used both family and hired labor more than the out- growers in Gimbo district

Tea plucking requires a skillful labor and growth of tea leaves depends upon the picking techniques. Moreover, quality of tea also depends on the picking (plucking standard) of the leaves. As a result, plucking of green leaf mostly handled by hired labor so as to keep good regeneration, timely supply to the factory and keep quality of the tea. The price of hired labor to pluck a kg of green tea leaves was ETB 1.50 and ETB 1.0 for export and local market standards, respectively. As shown in figure 5, the contribution of family labor in plucking leaves was very low.

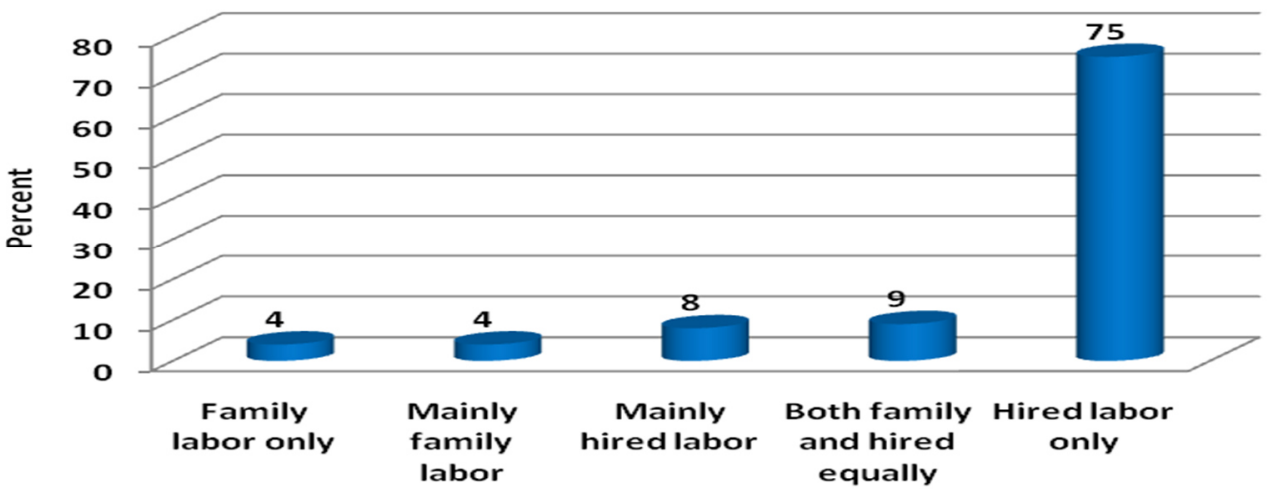

Figure 5. Out growers use of labor for plucking tea leaves

Tea yield was not the same round the year. There is a wide variation in the monthly yield. The two main seasons such as main (rainy) season and off-season (dry season) affect quantity and quality of tea production. In main season, high yield per unit area, short frequency of plucking and plucked mainly export standard. In other hand, in dry season out growers get very low yield, long frequency of harvesting and mainly harvested for local standard. As shown in figure 6 below, more out-growers plucked export standard green leaves in main season and harvested twice per month. In other hand, very low frequency and local standard was plucked in dry season.

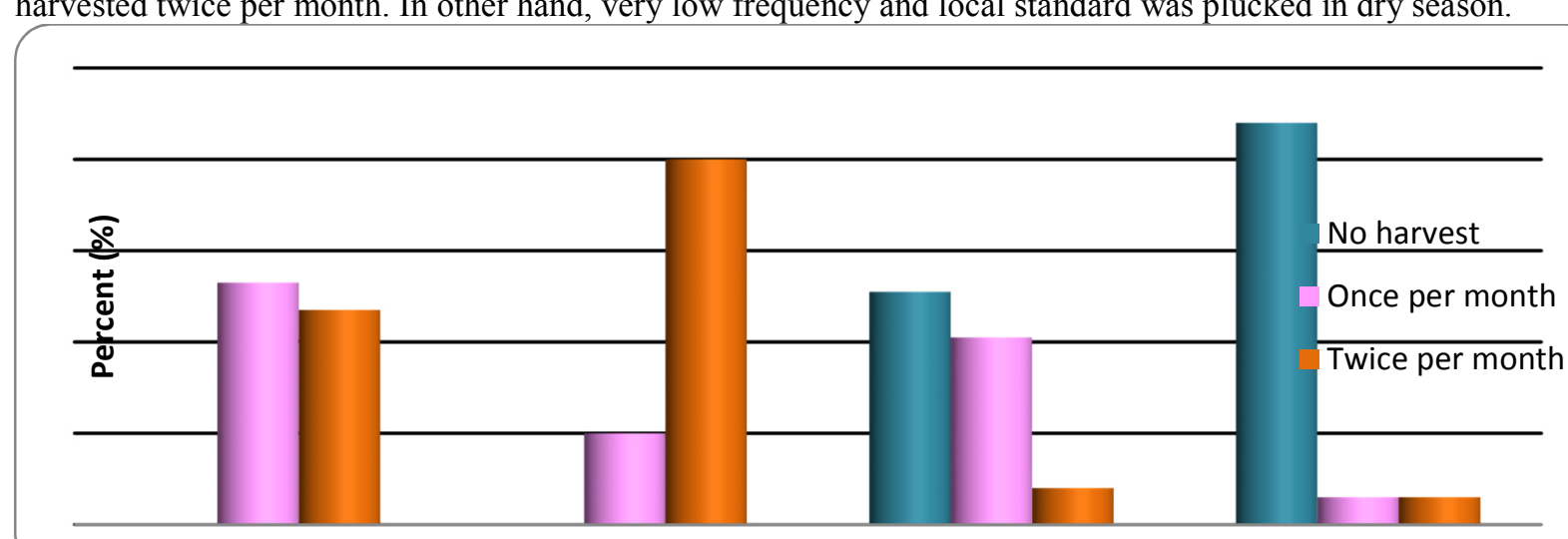

Figure 6. Seasons and standards of tea plucking 
The quality of tea depends on types of plucking and transporting from farm gate to tea processing factory. Tea is perishable crop and if not reach on appropriate time, it loses its moisture which result in reducing quality of tea. Tea is plucked in two standards namely export and local quality standards. The Export quality standard is when the top two leaves and a bud (succulent youngest leave) is plucked from tea bush. If it is plucked more than this leaves standard, it is considered as local which processed and supplied to domestic market. In the study areas, out growers plucked tea leaves for nine months per year. They plucked on average for nearly six months in main/rainy season and three months in dry season. There was significant difference in number of months plucked between out growers surrounding Wush Wush and Gumero tea plantations. They plucked export standard 1.8 times per month and plucked 1.5 times per month for local. Out growers plucked on average $295 \mathrm{~kg} / \mathrm{ha}$ export standard and $731 \mathrm{~kg} / \mathrm{ha}$ local standard in one harvest in the main season. This quantity dropped to $206 \mathrm{~kg} / \mathrm{ha}$ and $387 \mathrm{~kg}$ in dry season for export and local standards respectively. Farm gate price of green leaves was the same throughout the year. It was $5 \mathrm{ETB} / \mathrm{kg}$ for export standard and $3.5 \mathrm{ETB} / \mathrm{kg}$ for local standard. Price is determined based on standard of plucking and timely delivering of tea leaves to the factory. Almost all out growers not satisfied with the price set as the cost of tea production is very high (Table 5).

Table 5. Quantity and quality standards of tea plucked in main and dry seasons

\begin{tabular}{|c|c|c|c|c|c|c|c|c|c|}
\hline \multirow[t]{2}{*}{ Season } & \multirow[b]{2}{*}{ Variables } & \multicolumn{2}{|c|}{$\begin{array}{l}\text { Alle district } \\
\text { (Gumero) }\end{array}$} & \multicolumn{2}{|c|}{$\begin{array}{l}\text { Gimbo district } \\
\text { (Wush Wush) }\end{array}$} & \multicolumn{2}{|c|}{ Total } & \multirow[b]{2}{*}{$\mathrm{t}$} & \multirow[b]{2}{*}{ Sign. } \\
\hline & & mean & St.dv & mean & St.dv & mean & St.dv & & \\
\hline \multirow[t]{5}{*}{$\begin{array}{l}\text { Main } \\
\text { season }\end{array}$} & $\begin{array}{l}\text { Number of months } \\
\text { plucked }\end{array}$ & 6.12 & 1.32 & 5.42 & 1.09 & 5.76 & 1.24 & 3.228 & $0.002 * * *$ \\
\hline & $\begin{array}{l}\text { Frequency of } \\
\text { plucking per month } \\
\text { for export standard }\end{array}$ & 1.71 & 0.47 & 2 & 0.00 & 1.8 & 0.41 & -1.751 & $0.093^{*}$ \\
\hline & $\begin{array}{l}\text { Frequency of } \\
\text { plucking per month } \\
\text { for local standard }\end{array}$ & 1.57 & 0.48 & 1.42 & 0.50 & 1.5 & 0.49 & 1.616 & 0.109 \\
\hline & $\begin{array}{l}\text { Green leaf plucked in } \\
\text { one harvest for export } \\
\text { standard (kg/ha) }\end{array}$ & 303 & 337 & 281 & 168 & 295 & 284 & 0.328 & 0.744 \\
\hline & $\begin{array}{l}\text { Green leaf plucked in } \\
\text { one harvest for Local } \\
\text { standard (kg/ha) }\end{array}$ & 661 & 437 & 817 & 469 & 731 & 461 & -1.765 & $0.080^{*}$ \\
\hline \multirow[t]{5}{*}{$\begin{array}{l}\text { Dry } \\
\text { season }\end{array}$} & $\begin{array}{l}\text { Number of months } \\
\text { plucked }\end{array}$ & 2.69 & 0.82 & 3.2 & 1.38 & 2.94 & 1.15 & -1.779 & $0.080^{*}$ \\
\hline & $\begin{array}{l}\text { Frequency of } \\
\text { plucking per month } \\
\text { for export standard }\end{array}$ & 1.42 & 0.52 & 2 & 0.00 & 1.5 & 0.52 & -1.549 & 0.583 \\
\hline & $\begin{array}{l}\text { Frequency of } \\
\text { plucking per month } \\
\text { for local standard }\end{array}$ & 1.17 & 0.37 & 1.17 & 0.38 & 1.17 & 0.38 & -0.058 & 0.954 \\
\hline & $\begin{array}{l}\text { Green leaf plucked in } \\
\text { one harvest for export } \\
\text { standard (kg/ha) }\end{array}$ & 177 & 110 & 255 & 155 & 206 & 131 & -1.527 & 0.139 \\
\hline & $\begin{array}{l}\text { Green leaf plucked in } \\
\text { one harvest for Local } \\
\text { standard (kg/ha) }\end{array}$ & 384 & 380 & 399 & 206 & 387 & 300 & -0.191 & 0.849 \\
\hline
\end{tabular}

The growing of tea seems to be an attractive venture for out-growers as it provides work and income throughout the year. Farmers diversify their income using different sources. In the study areas, tea is one of the main sources of income next to coffee. About $57 \%$ of out-growers main source of income was coffee. Tea provides long term return and lower risk crop. However, many out growers showed no sign of livelihood improvement in tea growing. Out-growers spent income generated from tea more on household consumption and inputs such as fertilizer, labor, etc (Figure 7 and Figure 8). 


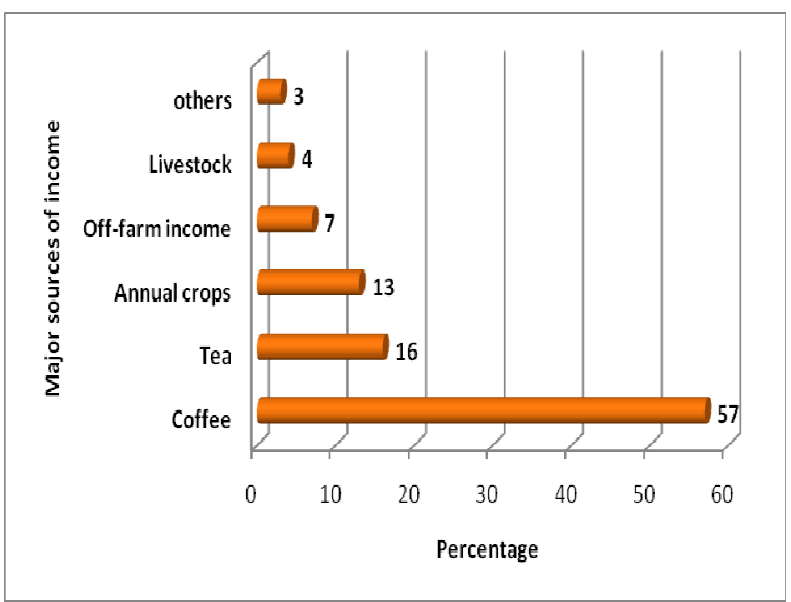

Figure 7.Out-growers major sources of income.

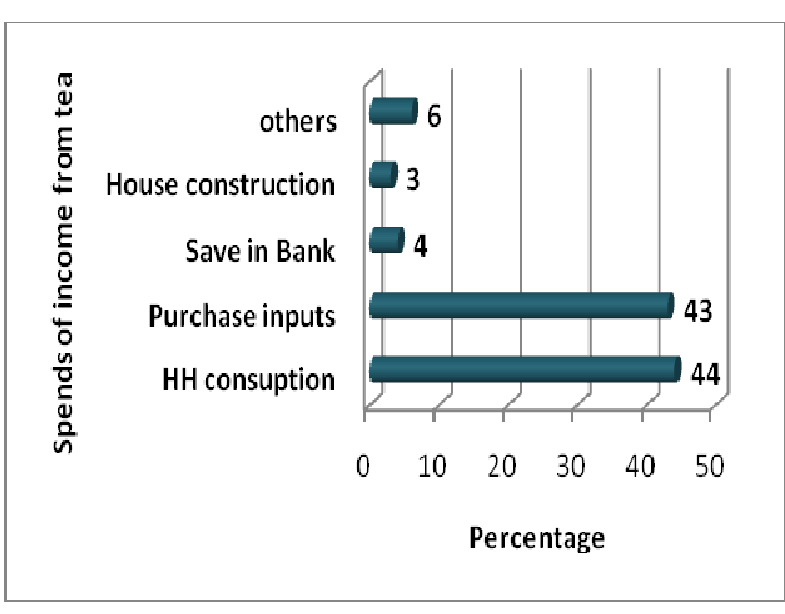

Figure 8. Spent of income from tea

Tea out-growers in the study areas arranged with the nucleus estate or out-growers model where a firm enterts a production node through an estate or plantation but also contracts with independent producers for greater volumes (Martin Prowse, 2012). Farmers in the surrounding areas of tea plantations involved in contractual agreements through their cooperatives. The tea plantations provided seedlings (free of charge), inputs, transportation of product from farm gate and technical supports. The contract agreement made in advance for terms of sale of output, price level, specific quality, date of delivery, production and marketing risk, termination of contracts, etc. In the study areas as the agreement made between out growers' cooperatives and estates, sometimes they fail to include some basic details in contracts and out growers are not fully informed about the nature of the agreement they are entering into. The result showed that they were fully aware on agreements made on input supply and product transporting service. However, they have different perception on duration and season of agreement made, price agreement, agreements on production and marketing risk, etc. According to out-growers perception, $51 \%$ of them made agreement during harvesting time and $68 \%$ of them perceived that agreement on production and marketing risk management was not made (Table 6).

Table 6: Out growers perceptions on the agreements made between cooperatives and estates

\begin{tabular}{|c|c|c|c|c|c|c|c|c|c|}
\hline \multirow[t]{2}{*}{ Variables } & \multirow[t]{2}{*}{ Catagory } & \multicolumn{2}{|c|}{$\begin{array}{l}\text { Alle district } \\
\text { (Gumero) }\end{array}$} & \multicolumn{2}{|c|}{$\begin{array}{l}\text { Gimbo } \\
\text { district } \\
\text { (Wush } \\
\text { Wush) }\end{array}$} & \multicolumn{2}{|c|}{ Total } & \multirow[t]{2}{*}{ Chi 2} & \multirow[t]{2}{*}{ Sign. } \\
\hline & & $\mathrm{n}$ & $\%$ & $\mathrm{n}$ & $\%$ & $\mathrm{n}$ & $\%$ & & \\
\hline \multirow[t]{3}{*}{ Season of agreement } & $\begin{array}{l}\text { Before } \\
\text { planting }\end{array}$ & 17 & 14 & 24 & 20 & 41 & 35 & \multirow[t]{3}{*}{10.897} & \multirow[t]{3}{*}{$0.004 * *$} \\
\hline & $\begin{array}{l}\text { At planting } \\
\text { time }\end{array}$ & 2 & 2 & 12 & 10 & 14 & 12 & & \\
\hline & $\begin{array}{l}\text { At harvesting } \\
\text { time }\end{array}$ & 38 & 32 & 25 & 21 & 63 & 53 & & \\
\hline \multirow{2}{*}{$\begin{array}{l}\text { Is pre-determined Price } \\
\text { agreement made }\end{array}$} & Yes & 44 & 37 & 46 & 39 & 90 & 76 & \multirow[t]{2}{*}{0.003} & \multirow[t]{2}{*}{0.954} \\
\hline & No & 14 & 12 & 15 & 13 & 29 & 24 & & \\
\hline \multirow{2}{*}{$\begin{array}{l}\text { Agreement made on risk } \\
\text { management }\end{array}$} & Yes & 16 & 13 & 23 & 19 & 39 & 32 & \multirow[t]{2}{*}{1.236} & \multirow[t]{2}{*}{0.266} \\
\hline & No & 42 & 35 & 39 & 33 & 81 & 69 & & \\
\hline
\end{tabular}

Constraint is a specification that should be met; otherwise certain definable negative consequences will follow. Main constraints of small scale farmers are access to resource and market. They have limited resources and with the rise of living they unable to get the optimum level of output for the input provided. As a result they are hindered to improve production and supply good quality of product. The cost of tea growing from planting to maturity is huge and needs more investment than other crops (Elias et. al., 2012). Out-growers in the study areas have many constraints that hindered improved production and supply of good quality of leaves growing tea. These constraints are categorized as in relation to inputs, production, technology use and extension.

\section{Constraints related to Inputs}

Tea growing requires intensive inputs such as fertilizer, chemicals and labor. Fertilizer and chemicals were supplied by the tea estates (Wush Wush and Gumero Tea Developments). Fertilizer supplied in the form of credit in which deduct from out growers income received from green leaves sales. However, out growers did not know the price of fertilizer and how to compute deduction. This is a major problem of out growers supplying tea leaves 
to Gumero plantation in Alle district. Another major constraint of out growers was the high price of inputs (fertilizer and labor). This is a major problem of out growers at Wush Wush plantation in Gimbo district. Tea seedlings were supplied to them by the Tea Development Farms free of charge. Tea seedlings production requires skill and none of them produce seedlings. To expand their tea farms, they faced shortage of seedlings. Moreover, timely availability of inputs, road accessibility to transport inputs was the major constraints in the study areas.

Constraints related to inputs were ranked based on the Relative Severity Index (RSI) values and rankings were assigned to each problem to identify the severity of each problem which is presented in Table 8 below. The higher the value of RSI, the problem was considered as high important or it is a serious issue and vice versa. Accordingly, the most three constraints related to inputs were high price of inputs, timely availability of inputs and shortage of input supply. The first serious problem such as high price of fertilizer and labor increased the cost of production which discourage out growers and result in frequently claim on the price of green leaves supplied.

Table 7. Major constraints related to Inputs in the study areas

\begin{tabular}{|c|c|c|c|c|c|c|c|}
\hline \multirow[b]{3}{*}{ Variables } & \multicolumn{4}{|c|}{ Scale } & \multirow{3}{*}{$\begin{array}{l}\text { Total } \\
\text { weighted } \\
\text { scale }\end{array}$} & \multirow{3}{*}{$\begin{array}{c}\text { Relative } \\
\text { Severity } \\
\text { Index } \\
\text { (RSI) }\end{array}$} & \multirow[b]{3}{*}{ Rank } \\
\hline & \multicolumn{2}{|c|}{$\begin{array}{l}\text { Constraint } \\
(\text { weight=5) }\end{array}$} & \multicolumn{2}{|c|}{$\begin{array}{l}\text { Not constraint } \\
(\text { weight }=1)\end{array}$} & & & \\
\hline & Freq & $\begin{array}{c}\text { Weighted } \\
\text { scale }\end{array}$ & Freq & $\begin{array}{c}\text { Weighted } \\
\text { scale }\end{array}$ & & & \\
\hline price of fertilizer not known & 20 & 100 & 100 & 100 & 200 & 0.32 & 4 \\
\hline High price of input & 51 & 255 & 69 & 69 & 324 & 0.54 & 1 \\
\hline Timely availability of inputs & 24 & 120 & 96 & 96 & 216 & 0.36 & 2 \\
\hline Shortage of inputs & 20 & 100 & 100 & 100 & 200 & 0.33 & 3 \\
\hline Road access to transport inputs & 7 & 35 & 113 & 113 & 148 & 0.25 & 5 \\
\hline
\end{tabular}

\section{Constraints relater to production and marketing}

Out growers have limited resources and with the rise of living they are unable to get the optimum level of output for the inputs provided. They faced several challenges to improve production of tea leaves. In the study areas, the major production and marketing constraints were high cost of production, lack of capital, drought, weed and intensive management. Constraints such as weed, erosion and termite were major problems of out-growers at Gumero Tea Development farms.

The most three constraints in tea growing were intensive farm management, high cost of production and lack of capital. Tea is a labor intensive activity which requires high labor in production. The activities such as hole digging, planting, pruning and plucking is done manually. Moreover, it is plucked almost year round and needs timely management. Lack of adequate family labor, inability to hire labor and lack of capital were the major problems out growers faced to manage tea fields and improve tea productivity. Therefore, intensive tea field management and lack of capital were the most sever constraints in producing tea. Cost of production was another major problem in tea farming as the cost of fertilizer and labor (major inputs) were very high. They may lack labor to pluck tea which makes tea plucking price to increase. Moreover, the cost of weeding, pruning, and plucking were very high. For example, a worker received 1.5 ETB when plucked one kilogram of export quality standard green tea leaves. However, out growers sell one kilogram export standard green tea leaves with 5 ETB. This implies that, workers that plucked green tea leaves take $30 \%$ of out growers selling price. Another major constraint was climate change such as drought. Out growers depends on rain fed agriculture and prolonged dry season drop production by large amount. Even though the two study areas are in different regions, there is no difference on most constraints they have faced (Table 8). 
Table 8. Major constraints related to tea production in the study areas

\begin{tabular}{|c|c|c|c|c|c|c|c|}
\hline \multirow[b]{3}{*}{ Variables } & \multicolumn{4}{|c|}{ Scale } & \multirow{3}{*}{$\begin{array}{l}\text { Total } \\
\text { weighted } \\
\text { scale }\end{array}$} & \multirow{3}{*}{$\begin{array}{c}\text { Relative } \\
\text { Severity } \\
\text { Index } \\
\text { (RSI) }\end{array}$} & \multirow[b]{3}{*}{ Rank } \\
\hline & \multicolumn{2}{|c|}{$\begin{array}{l}\text { Constraint } \\
(\text { weight }=5)\end{array}$} & \multicolumn{2}{|c|}{$\begin{array}{l}\text { Not constraint } \\
(\text { weight }=1)\end{array}$} & & & \\
\hline & Freq & $\begin{array}{l}\text { Weighted } \\
\text { scale }\end{array}$ & Freq & $\begin{array}{c}\text { Weighted } \\
\text { scale }\end{array}$ & & & \\
\hline High cost of production & 30 & 150 & 90 & 90 & 240 & 0.40 & 2 \\
\hline Drought & 23 & 115 & 97 & 97 & 212 & 0.35 & 4 \\
\hline Lack of capital & 25 & 125 & 95 & 95 & 220 & 0.37 & 3 \\
\hline Need intensive management & 32 & 160 & 88 & 88 & 248 & 0.41 & 1 \\
\hline Weed & 11 & 55 & 109 & 109 & 164 & 0.27 & 5 \\
\hline Erosion & 7 & 35 & 113 & 113 & 148 & 0.25 & 6 \\
\hline Termite & 7 & 35 & 113 & 113 & 148 & 0.25 & 6 \\
\hline
\end{tabular}

\section{Constraints related to extension services}

Extension services such as training, demonstration, field days, contact with farmers and visiting farmers' fields address gaps in information, knowledge and technology use. Contact with extension workers make farmers access to information on recommendation, gives advice on inputs and management of technologies. Most of tea farming practice is knowledge intensive activities and extension services through assistance, training and engaging farmers in tea technology demonstration make out growers to increase green leaf production. In the study areas, extension service provided only by the two tea development farms which was insufficient. Moreover, the role of government in coordinating tea sector is largely missing. There were no extension services provided and interventions made by the government extension agents to assist tea out growers. Out growers in Alle district surrounding Gumero Tea Development farm have more problem of accessing extension services than out growers surrounding Wush Wush Tea development.

Farmers with access to extension services achieve higher yields than farmers without access to extension services. The top three constraints related to extension services were no government extension services, lack of training and no government intervention. Out growers in the study areas accessed extension services and training only from Wush Wush and Gumero Tea plantation. Lack of training was the second major constraint. For example, production tea seedling requires skills. As a result, none of the out growers can produce seedlings by themselves. The result showed that, the government provided little focus to tea sector. As a result, there was no government extension service provided and intervention made by the government authority (Table 9).

Table 9. Major constraints related to extension services in the study areas

\begin{tabular}{|c|c|c|c|c|c|c|c|}
\hline \multirow[b]{3}{*}{ Variables } & \multicolumn{4}{|c|}{ Scale } & \multirow{3}{*}{$\begin{array}{l}\text { Total } \\
\text { weighted } \\
\text { scale }\end{array}$} & \multirow{3}{*}{$\begin{array}{l}\text { Relative } \\
\text { Severity } \\
\text { Index } \\
\text { (RSI) }\end{array}$} & \multirow[b]{3}{*}{ Rank } \\
\hline & \multicolumn{2}{|c|}{$\begin{array}{l}\text { Constraint } \\
(\text { weight }=5 \text { ) }\end{array}$} & \multicolumn{2}{|c|}{$\begin{array}{l}\text { Not constraint } \\
\text { (weight }=1 \text { ) }\end{array}$} & & & \\
\hline & Freq & $\begin{array}{l}\text { Weighted } \\
\text { scale }\end{array}$ & Freq & $\begin{array}{l}\text { Weighted } \\
\text { scale }\end{array}$ & & & \\
\hline Lack of training & 50 & 250 & 70 & 70 & 320 & 0.53 & 2 \\
\hline Lack of technical support & 23 & 115 & 97 & 97 & 212 & 0.35 & 4 \\
\hline Lack of extension services & 19 & 95 & 101 & 101 & 196 & 0.33 & 5 \\
\hline No government extension service & 51 & 255 & 69 & 69 & 324 & 0.54 & 1 \\
\hline No government intervention & 37 & 185 & 83 & 83 & 268 & 0.45 & 3 \\
\hline
\end{tabular}

\section{Opportunities of tea growing in the study areas}

Tea is an important crop in terms of job creation and income generation. As it is a labor intensive commodity, it provides employment opportunity particularly for rural community. It is also important for export earning and rural infrastructure development. In the study areas, the three most important opportunities in tea growing were generate high income compared to other annual crops, free from risk of theft and wild animals. As it is a natural forest area, producing annual crop particularly maize is difficult due to wild animals and provides continuous (plucked every two or three weeks) and year round income. Most of the time, farmers faced money or food shortage in summer (when crops are on the field), during this time tea out-growers not faced such problem as they generate continuous income. Tea also crates employment opportunities for many people in rural areas and being a long life crop (more than 50 years) it can be inherited to next generation. In Alle district, continuous year round income and minimum risk of producing tea were considered as the most important opportunities in the area (Graph 9). 


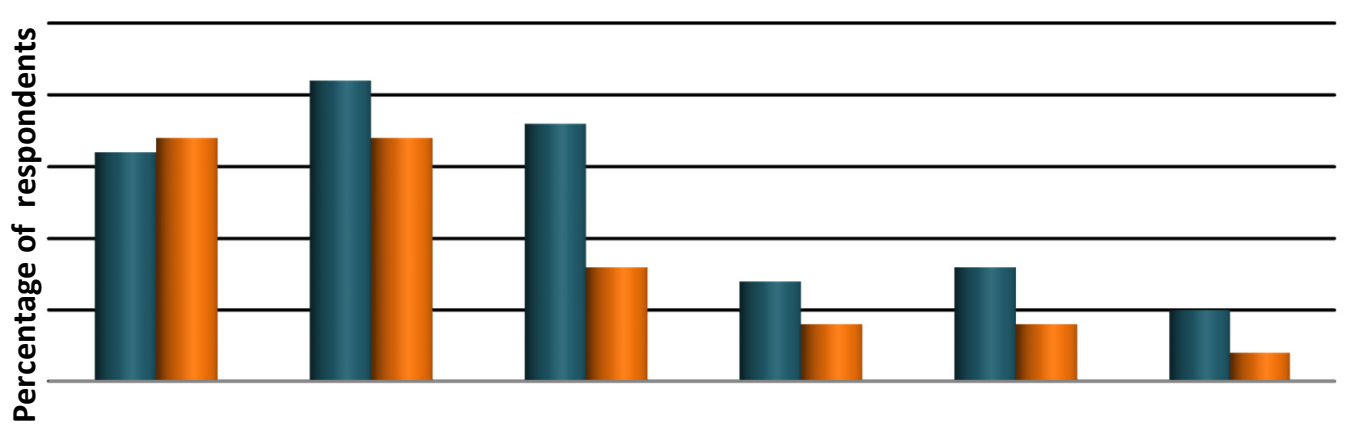

Graph 9. Major opportunities of growing tea in the study areas

The study areas are one of the most natural forest coverage areas in the country. There are many wild animals in the forest that damage annual crops on the field. This is a serious problem in the areas that is why out growers considered tea growing as the most important opportunity to minimize risk of wild animals and free from theft. The crop is important in generating high income related to other annual crops. Moreover, it provided a continuous year round income which help out growers to secure problem of money shortage during summer season.

\section{Conclusions and Recommendations \\ Conclusions}

The study tried to assess constraints and opportunities of tea out growers in south west Ethiopia. Tea is an important crop of out growers as most of them allocated large part (33\%) of their total farm land holding to tea. Moreover, tea is the second most important sources of income next to coffee in the study areas. The crop requires intensive inputs mainly fertilizer and labor which have significant impact on tea production. Plucking was the main cost of out growers which requires high hired labor during harvesting. The cost of plucking was $30 \%$ of the selling price of export standard green leaves. Regard to fertilizer application, they applied $236 \mathrm{~kg} / \mathrm{ha} /$ year fertilizer which were less by $21 \%$ from the recommended rate of $300 \mathrm{~kg} / \mathrm{ha} /$ year. Production of the crop showed on average 2600 $\mathrm{kg} / \mathrm{ha} /$ year green leaves which were below potential and below the two Tea Development farms which were 3500 $\mathrm{kg} / \mathrm{ha} /$ year. The decrease in production may be due to not used recommended rate of fertilizer application and practiced improved agronomic practices.

The contract agreement made in advance for terms of sale of output, price level, specific quality, date of delivery, production and marketing risk, termination of contracts, were not fully informed to out growers. They were fully aware on agreements made on input supply and product transporting service. However, they have less knowledge on price agreement, agreements on production and marketing risk which made out-growers not satisfied on the price of green leaves.

Constraints of out-growers in tea production, productivity and quality were prioritized using Relative Severity Index (RSI) approach. Accordingly, the major constraints were high price of fertilizer and labor especially for plucking as well as inputs were not timely supplied to out growers. These in turn result in high cost of production to produce tea. As the crop need intensive management, out-growers unable to supply the required inputs to produce optimal level of outputs and keep quality of green leaves supply. This was due to lack of capital and limited resources with the rise of living. Moreover, prolonged dry season or drought, high weed infestation and lack of government extension services were the main constraints in tea production.

Tea out growers have opportunities in generating continuous year round cash income, low risk of theft and wild animal damage and generate high cash income related to annual crops. Moreover, it created job opportunities for rural community which reduced migration of rural to urban to seek job. Out-growers considered the crop as insurance as they become older and as asset which can be inherited to family in next generation.

\section{Recommendations}

- As tea seedling production requires skill, no out growers can produce by themselves. However, there is high demand for seedlings in which the supply can't meet the demand. Therefore, out growers should be trained and supported by research centers and CTDMA in self seedling production. 
- The high cost of tea production due to intensive use of fertilizer and hired labor reduced revenue from tea .sales. Therefore, cost saving strategies should be highly addressed. These are technology use like simple hand harvesting machine and hired labor management to increase labor efficiency.

- Tea production need intensive inputs such as fertilizer and labor particularly at harvesting. At this time out growers may lack money to hire labor for plucking. They also lack capital to expand tea farm land. Therefore, it needs to strengthen out growers by facilitating credit access and debit management services.

$\circ$ Strengthen tea cooperative where out growers can share tea farming information and negotiate for better contractual terms with estates.

- Government and privates should be well coordinated to develop a broader approach that can effectively address challenges facing tea out growers. It needs to encourage out- growers in tea farming activities by attracting them with farming related incentives such as subsides and reasonable farm gate price.

○ Out growers highly claim low price of tea leaves sold. Revenue not covers their production cost. Therefore, it needs further research on profitability and efficiency of tea production by out- growers.

\section{References}

Chandima W., Emmanuel F., Anoma J.M., Sanath J.K., 2017. Prospects and issues related to tea cultivation in mid country homegarden based tea smallholdings in a selected village in Sri Lanka. Tropical Agricultural Research · December 2017 DOI: 10.4038/tar.v28i4.8250.

CSA, 2015.Agricultural Sample Survey. Report on Area and Production of Major Crops for Private Peasant Holdings, Meher Season. Addis Ababa.

EIAR 2017, National Tea commodity research strategy (2016-2030), January 2017, Addis Ababa.

Elias K., Sarah W. and Kagwathi S., 2012. Sustainable method of addressing challenges facing smallholder tea sector in Kenya. A supply chain management approach.

Martin PROWSE, 2012. Contract Farming in Developing Countries - A review. A SAVOIR. Institute of Development policy and management, University of Antwerp.

MoFED, 2010.Growth and Transformation Plan I. Addis Ababa Ethiopia.

Sharma, V.K., A. Bhattacharya, A. Kumar and H.K. Sharma, 2007. Health benefits of tea consumption. Trop. J. Pharm. Res., 6: 785-792

Yamane, Taro, 1967. Statistics, An Introductory analysis, $2^{\text {nd }}$ Ed., New York: Harper and Row. 